\title{
Corrigendum
}

\section{Corrigendum to "Effects of Nanoimprinted Structures on the Performance of Organic Solar Cells"}

\author{
Hardeep Singh Gill, ${ }^{1,2}$ Lian Li, ${ }^{1,2,3}$ Haizhou Ren, ${ }^{1}$ Ravi Mosurkal $\mathbb{D}^{3}{ }^{3}$ and Jayant Kumar $\mathbb{D}^{1,2}$ \\ ${ }^{1}$ Department of Physics, University of Massachusetts Lowell, Lowell, MA 01854, USA \\ ${ }^{2}$ Center for Advanced Materials, University of Massachusetts Lowell, Lowell, MA 01854, USA \\ ${ }^{3}$ US Army Natick Soldier Research, Development and Engineering Center, Natick, MA 01760, USA \\ Correspondence should be addressed to Ravi Mosurkal; ravi.mosurkal.civ@mail.mil and Jayant Kumar; jayant_kumar@uml.edu \\ Received 5 September 2018; Accepted 18 September 2018; Published 5 November 2018 \\ Copyright (C) 2018 Hardeep Singh Gill et al. This is an open access article distributed under the Creative Commons Attribution \\ License, which permits unrestricted use, distribution, and reproduction in any medium, provided the original work is \\ properly cited.
}

In the article titled "Effects of Nanoimprinted Structures on the Performance of Organic Solar Cells" [1], there is a missing corresponding author where Dr. Ravi Mosurkal should be listed as the first corresponding author.

\section{References}

[1] H. S. Gill, L. Li, H. Ren, R. Mosurkal, and J. Kumar, "Effects of nanoimprinted structures on the performance of organic solar cells," Journal of Nanomaterials, vol. 2018, Article ID 7401974, 6 pages, 2018. 


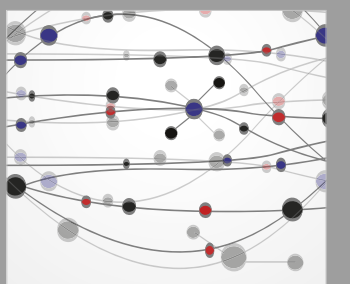

The Scientific World Journal
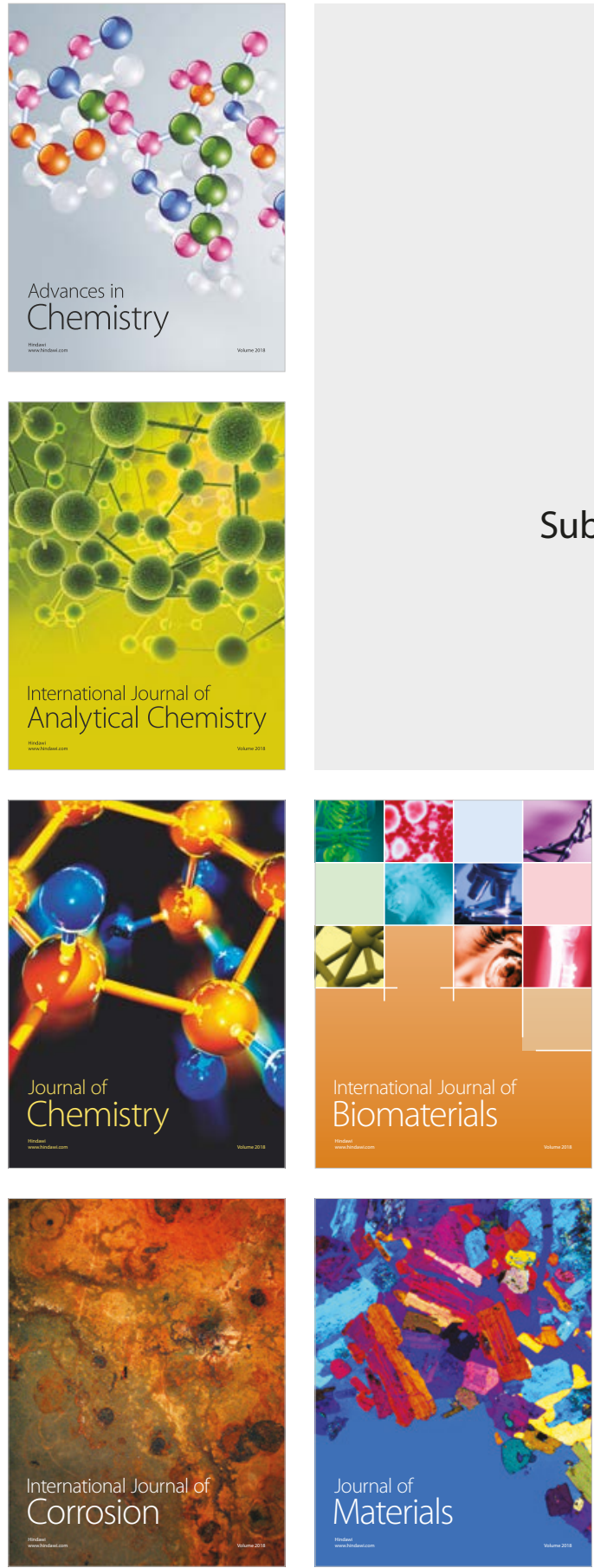

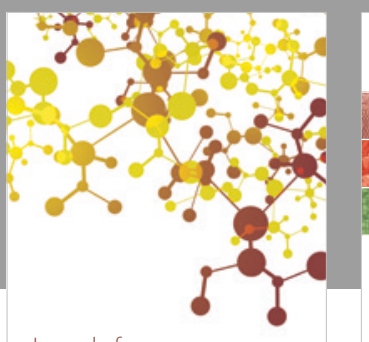

Journal of

Applied Chemistry
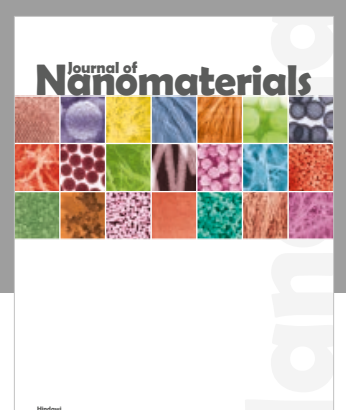

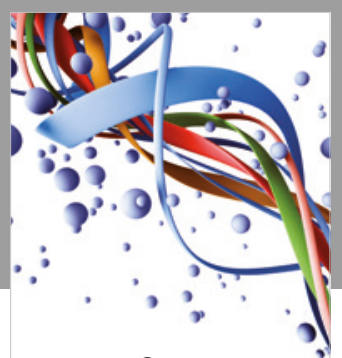

Scientifica

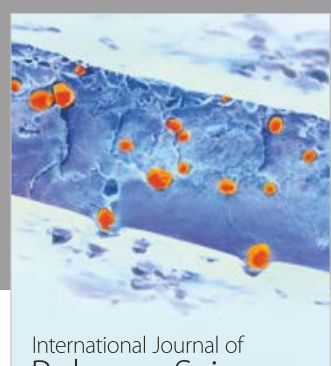

Polymer Science

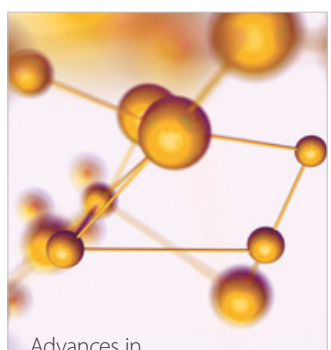

Physical Chemistry
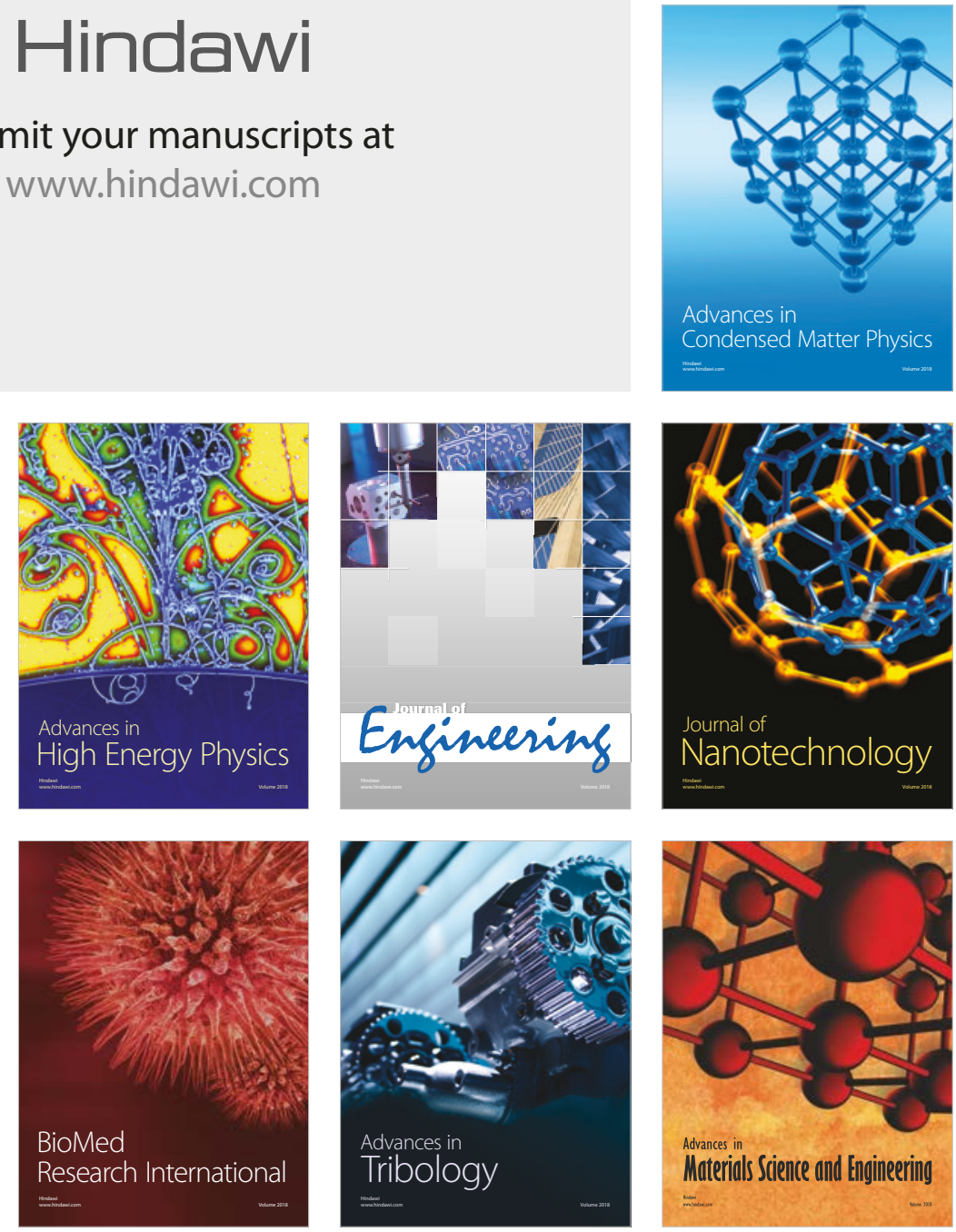